\title{
The Role of Institutional Investors in the Evolutionary Dynamics of Agro-food Enterprises
}

\author{
Vincenzo Formisano, Maria Fedele, Emanuela Antonucci \\ University of Cassino and Southern Lazio, Cassino, Italy
}

\begin{abstract}
The research topic is the one of public finance company whose core business is focused to support investment projects to overcome enterprises technological and structural gap. The research question is: If and how a public finance company is able to create and favor value creation processes sustainability for agro-food enterprises, highlighting the positive emerging externalities for different categories of stakeholders. They have results with particular evidences allow comparisons between the private investments and the support of institutional public investors. In such perspective, the mode of disbursement of soft loans and investment operations made by a public financing company will be examined. The methodological approach used, following a deductive-inductive perspective, is based on the case study. Such technique able to formulate theories about a little known phenomena in their context, allows the study of recent events on which the researcher has little control. To this, a qualitative analysis on both primary and secondary data adds. From data analysis, it resulted that the Institute of Agribusiness Development (ISA) initiatives facilitated, just for example, the technological innovation of production department and consequent production capacity, the acquisition of production assets for row material processing and optimization of internal logistics, through an innovative automated warehouse. As a result, the case study finds sustainability at multiple levels reached by the activities promoted by ISA and the subsequent co-creation of value for stakeholders involved, small agro-food businesses innovation, and/or internationalization processes. As long as practical implications are concerned, such highlight the importance and the need for public and private institutions in their effort to continue to invest in projects to support the economy of the country. The originality of the paper lies in the proposed interpretation of more integrative paradigms (viable system approach, sustainability, and, value creation), analyzing a financial institution for the development of the Italian food industry. At the same time, authors stress the research limit that is the analysis of the input of only one organization and consequent limited data in quantity and time span.
\end{abstract}

Keywords: public finance company, shared value creation, sustainability, agro-food context, investment projects

\section{Introduction}

In a national and international context characterized by high uncertainty and deep changes, it is critical for the country, because of both its geographical location and features, to attempt to capture and analyze

Vincenzo Formisano, associate professor, Department of Economics and Law, University of Cassino and Southern Lazio, Cassino, Italy.

Maria Fedele, Ph.D. Graduate, Department of Economics and Law, University of Cassino and Southern Lazio, Cassino, Italy.

Emanuela Antonucci, Ph.D. Graduate, Department of Economics and Law, University of Cassino and Southern Lazio, Cassino, Italy.

Correspondence concerning this article should be addressed to Maria Fedele, University of Cassino and Southern Lazio, Via Sant'Angelo, s.n.c., 03043 Cassino (FR), Italy. E-mail: m.fedelecam@libero.it. 
opportunities for growth and development that are offered. With this assumption, it should deepen the study of the resources allowing to respond to current challenges. One of these is the territory as a resource including a number of factors which embrace food products to guarantee a sustainable economic and social development. The food sector has always been strategically important for the made-in-Italy "basket", designed to support the economy of the country and promote its image abroad. In fact, it accounts for $13.9 \%$ of the Italian GDP, a value in continuous growth since 2008, supported mainly by exports that can compensate for the stagnation of nationwide consumption. However, structural problems of the sector and of "national system" limit the full exploitation of the competitive potentialities of the sector itself on international markets. It should be noted that the set of internal and external stakeholders of the entire food industry is a significant support to the Italian economy, in front of a very high pulverized stages of production that hinders adequate investments in research and development (R\&D) that will make the system more competitive. However, the current situation is characterized by a low level of value creation for the several actors, due to a negative dynamic demand inducing to origin synergic processes in order to improve the productivity and competitiveness also through processes of food exports development. Just to increase the competitiveness of this sector, which in respect of the export ranks and keeps at the second place behind the engineering sector (Rossi, 2014), a proper public financial support is necessary for the development of the made-in-Italy quality, both nationally and internationally. Thus, the aim of this paper lies precisely in analyzing the role of a public finance company in terms of value creation processes sustainability for agro-food enterprises. In light of these considerations, the following research question was tested: Is it possible to create shared value by enabling synergies between public companies and private ones, even in particularly economic and financial adverse conditions? Some practical information will be also derived for the governance of agro-food businesses and their dimensional and competitive development. The article is structured as follows: After the introduction, in the first section, the role of sustainability in investment projects is analyzed; in the following, the issue of value orientation and its relationship with the management of the company financial structure will be addressed; in the second section, a case study will be analyzed and results obtained from the qualitative analysis will be discussed as well. In this context, the research hypothesis will be confirmed. The work will be completed with the conclusions, including implications, study limitations, and suggestions for future research.

\section{Theoretical Background}

\section{Role of Sustainability in Investment Projects}

The current economic and financial crisis stressed the concept of sustainability associated with the ability of companies to create value for all stakeholders, both primary and secondary ones, related to capital markets, corporate organization and external environment. The creation of value must be sustainable especially in a context such as the present one, characterized by high levels of complexity. Complexity meant the emergence of "always new scenarios that make the developments of events in time unpredictable" (Rullani, 2011, pp. 225-242), which has extended the number and frequency that adverse events can affect the viability of the business system (Golinelli, 2005). Here, then, is looming sustainability (Brown, 1981; Wilson, 2003; Savitz \& Weber, 2006; Crane \& Matten, 2007; Quaddus \& Siddique, 2011; Carroll \& Buchholtz, 2014; Benn, Dunphy, \& Griffiths, 2014), for an evolving dynamic enterprise characterized by conditions of harmony and resonance with the external environment. Being considered as a paradigm of business (Elkington, 1994; 
Edwards, 2005; Friedman, 2006; Blackburn, 2012), it should be understood as the integration of (Caroli, 2006; Siano, 2012):

- economic sustainability: essential constraint of the business - it involves the ability to create shared value through the remuneration of the staff, the creation of new jobs and maintaining relationships with customers, suppliers, and the financial system;

- environmental sustainability - companies in managing their business, are able to generate economic, social, and environmental externalities, according to the system of values and ethics, which can be positive and/or negative. The adoption of a cost-benefit approach in evaluating the sustainability of such activities would be likely to be influent in the phase of contracting, through the use of this economic-monetary approach to integrate in banking processes, for measuring the creditworthiness of environmental externalities. This would allow to select and promote worthiest behavior consistent with a strategy of long-term development;

- social sustainability - expressed in terms of the high safety standards of working conditions as well as education and health staff;

- financial sustainability - it indicates a company's ability to generate cash flows sufficient to cover all costs incurred and to generate an overall profit margin to fund the growth of the company; it is measured by the coefficient of debt or leverage (debt/equity) and NFP/EBITDA.

This assessment is essential for a dynamic evolution of the company characterized by conditions of consonance and resonance (Barile, 2006). The first is to be understood as structural compatibility through the creation of synergies with other systems, tending toward a common goal. The resonance allows the viable system to act in harmony and effectiveness by developing a unified vision with the context in which it lives, which boundaries are subject to continuous redefinition. It concerns forms of sharing and belonging accompanied by "empathy", progressively attenuating the effect of structural boundaries for a maximum degree of opening. Such determines, in terms of relation quality, increasing levels of trust and sharing of orientations and perspectives among the interacting systems (Golinelli \& Gatti, 2007). In such a context, they are both relevant role of institutional investors (Rappaport, 2012), expressed in terms of raising confidence among businesses and the social entrepreneur aimed to enhance relations with the stakeholder network through a social environmental sustainable development and innovation (Hall \& Vredenburg, 2003). The concept of value in terms of quality is generated with the social legitimacy of the enterprise and its governing body, both within the business context and in front of the actors who support its development (Lindgreen \& Swaen, 2010). In order to achieve these objectives, it is necessary for the enterprise system to be proactive (Valdani, 1992; Kickul \& Gundry, 2002), particularly with respect to the financial system: It means to evaluate constantly whether it responds effectively to demands, and if necessary, in evolutionary sense, to modify the operational structure. The behavior and the evolutionary process of the company, therefore, are influenced by the constraints of the financial supra-system (McMahon, 2001), with which it interacts, which leverages critical resource owned and made. From these considerations, it derives that sustainability is pursued effectively only when the entrepreneur is able to bring all the values of the various actors involved in the co-creation of value to the perfect harmony (Payne, Storbacka, \& Frow, 2008). Compliance with current and future expectations, therefore, reinforces the extension and the overcoming of stakeholder theory (Freeman, 1984, 1994, 2002; Evan \& Freeman, 1988; Carroll, 1993; Donaldson \& Preston, 1995; Jensen, 2002; Post, Preston, \& Sachs 2002; Freeman \& McVea, 2002) for the benefit of corporate sustainability (Golinelli \& Volpe, 2012). 


\section{The Value Orientation and the Management of the Company Financial Structure}

The adoption of an approach based on value implies a different role to be taken by the governing body with respect to the financial management of the company. In particular, a careful analysis, composition, and use of the financial structure are necessary, which should not only be induced to control the explicit cost of debt or equity, but also extend to the implications of financing on government choices of the firm (La Rocca, 2001). It is necessary to reconcile the objective of maximizing value with the ability to attract financial resources in order to establish a capital structure that reflects the business strategy that does not compromise its competitiveness (Modina, 2012). This concept is crucial in a context, such as the Italian one, characterized by an economy essentially made by small and medium-sized enterprises (SMEs), to examine the main sources of funding used to evaluate the financial strength and outline the typical features of demand for financial products and services (Castelli \& Modina, 2010). Value creation is the purpose for which management must strive, with the support of the owned capacity of the structure, providing a realistic development and/or growth project, the results of which exceed the expectations of investors, who awarding financial means, allow the viability and support the risk by the size of capital allocated (Marris, 1972; Giuliani, 2005). The plan must be conceived as a "temporal succession of states of the system, arising in turn from a sequence, still in time, of structural configurations up to that goal qualified by a law of functioning which leads to the expected results of operations" (Golinelli \& Gatti, 2007, pp. 207-255).

It is, as pointed out by Gatti, Biferali, and Volpe (2009) that,

A considerable shift in perspective: The definition of a project that, when projected over the long term, is able to ensure consonance of context which allows harmony between firm and its environment, and manifests itself in the capacity of generating a sharing on the designed project of the business evolutionary dynamics in greater awareness of the risks associated to, attracts the attention and loyalty of partners qualified to provide the company with valuable resources; the actors, however, are persuaded to take risks and sacrifice their expectations for the short term in the awareness; while the benefits will reward them in the long run. ( pp. 145-171)

In this context, the financial system builds the selection of investment projects just on value, favoring those that create with respect to those that destroy value. In relation to its own characteristics, the financial system exerts its power through expectations and pressures, ex ante, and a continuous monitoring of the evolution of the company, ex-post. The value makes it possible to take into account the need for self-perpetuation of the company and to survive in the long term, not under-evaluating the wider interests that move around it (Sciarelli, 2002). It must, therefore, qualify as "systemic", i.e., as a unit of benefits (monetary or not) that the enterprise system is capable of generating for all those who, for various reasons, participate or are interested in his story (Gennaro, 2008). It is closely related to the choice of managerial nature, competitive position, efficiency of the value chain, generation and exploitation of intangible resources (first of all the competencies). In addition to this, an equally important role lays in the choices inherent to the financial structure, which optimization will help to lower the overall cost of capital and does not suffer from restrictions on its availability. The value orientation allows, therefore, to assess, in a more comprehensive and accurate way than traditional ones, the strategic decisions of a company from an economic, competitive, social, and financial point of view (Faccipieri, 1989; Buttignon, 1990; Collis \& Montgomery, 1999; Grant, 2011). In the most advanced company configurations, it has become a real "philosophy" of management that tends to permeate the entire organization of the company.

Value represents the key around which businesses move and its creation are the very reason of their existence (Vicari, 1995). It is an expression of the wealth of the company, owned and distributed (Calabrese, 
Bologna, Iandolo, \& Bilotta, 2012). All these reasons explain the change of the classic paradigms that evolved toward a creation of value for the benefit not only of shareholders but of all stakeholders ( $\mathrm{Ng}$, Parry, Smith, \& Maull, 2010). According to Porter and Kramer (2011), the model of creating shared value drives the strategy and practices of companies to a higher level of competitiveness, in association with the improvement of the economic and social context in which they operate. This is able to generate competitive advantages often more sustainable with respect to benefits, costs, and quality of products. It is a form of capitalism that evolved, including at the strategic level (McWilliams \& Siegel, 2006), to achieve social goals, also allowing companies to increase their social legitimacy. The starting point is the analysis of the needs of the environment, in addition to the costs and benefits arising from the running of the business. This new approach is able to generate new economic development opportunities, which are constantly changing as a result of economic and social priorities. The creation of shared value can be considered as the "turning point" able to determine the "next wave of global growth" through innovation, development, and social benefits.

\section{Case Study: Institute of Agribusiness Development (ISA)—The Hypothesis Test}

In an environment experiencing the worst economic and financial crisis in decades, they are mainly smaller companies to face significant difficulties in obtaining adequate financial resources for the implementation of higher capacity to allocate in the evolutionary dynamics of high levels of sub-system and supra-systemic consonance. From such considerations, the following hypothesis arises. The creation of shared value highlights the role played not only by private companies but also by public financing institutions about improving techniques to support opportunities for wealth creation for the different categories of stakeholders. In order to test this hypothesis, this paper has analyzed the characteristics of a public financing company, whose core business is to support investment projects to bridge the technological and structural gap in the agro-industrial sector. After defining the goal of the study, the desk analysis has allowed the identification of the essential points of the project format, identified in the definition of the objective to be pursued and in the procedures for data gathering, through the determination of the sources of information and research question relevant to the case study. Then, it has specified the guidelines for the preparation of the paper, as indicated below, which led the working group to select ISA as representative case of the phenomenon under investigation. The acquisition of the primary data was made through an interview with a manager of ISA, considered as an authoritative source of knowledge of the reality under study; the latter, however, was found through the analysis of books and scientific articles, databases (EBSCO and Google scholar) and public source (website and documents published by ISA).The ISA is, in fact, a holding company with a sole shareholder, the Ministry of Agriculture, Food and Forestry (MIPAAF), which since December 2005 operates with non-speculative goals, financing productive investment and capitalizes the agro-food businesses in order to support aggressive business plans and the internationalization of exporting companies. It is equipped with a structure owning specific skills able to understand the dynamics of the market and competitive leverages, the needs of the industry, growth factors, the know-how needed to perform corporate finance transactions. ISA addresses economically and financially healthy to companies and cooperative societies, whose profitability is demonstrated, operating in the sectors of transformation and sales of agriculture, livestock, and forestry products. With a continuous and exclusive focus on the needs and potentiality of the sector, the ISA becomes a promoter of strategic, operative, and commercial choices, aimed at enhancing the level of competitiveness and innovation of the Italian agro-food sector, improving, also, at the structural level of the income of agricultural 
producers. Its activity is addressed to new business initiatives, programs of adjustment, and restructuring of existing plants, and to product diversification implemented through products and/or process innovations, till the realization of plants for power generation from renewable sources. ISA intends to favor investment projects which seek to:

- increase the size of the company through mergers, networks, joint ventures, strategic alliances, and holding;

- reach a critical mass of products that strengthen market presence in order to upgrade sales on foreign markets;

- innovate and expand the current production in response to the new demands of the market, valorizing local products and creating a traceability system to escape the tight price competition.

In addition to the typical activities of providing low-interest loans, ISA supports investment transactions to encourage new business initiatives that will meet the needs of an increasingly flexible and dynamic market. In line with the principles of the market economy, it may acquire minority interests and provide funding for the consolidation and development of enterprises. The operations must be carried out at market value as input, expected return, and corporate relations with a final exit; they must not require any disengagement of private parties. Companies cannot take advantage of the both opportunities offered by ISA. During the preparatory technical credit stage, aimed at verifying the credit and the design method, the ISA proceeds with the verification of different aspects: the credibility of the proposed project, paying particular attention to the reasonableness of the assumptions and shareability of the industrial, financial, and market assumptions, especially with regard to the ability to repay the loan required, in the interests of healthy and balanced management. Another important aspect in the assessment is the definition of eligible warranties and the contractual framework, adequate to protect and monitor potential investment, so that they can be activated quickly and effectively without "stopping" the normal run of business. There are, finally, effective sanctions for non-compliance. At the moment of validation of the project by the ISA Board of Directors, it follows the authorization of the MIPAAF and notification to the European Commission which has indicated the principles to be followed for applying the intervention on risk capital. The criteria to follow relate to the situation of the company, which must be economically and financially "healthy" in order to increase and improve its capacity to expand the competitiveness which undertakes corporate integration processes and establishes the connection with the productive sector at the base of the supply chain; the profitability of the intervention must be appropriate to the performance of the sector; the contribution of the financial holding company shall not exceed the actual value of the company and should be proportional to the participation of private investors. ISA wants to play both the roles of institutional investors and promoter of strategic decisions, marketing initiatives and operative decisions in order to encourage the consolidation and development of the Italian agro-food sector.

Special rules govern "contracts of sector", between the actors of the food chain and the MIPAAF. The goals wish to pursue, involves the implementation of an investment program of inter-professional nature and having national significance, to facilitate the integration of the supply chain of the agricultural and food systems as well as the strengthening agro-industrial depressed areas of the Italian territory.

Therefore, ISA supports manufacturers financially, strategically, commercially, and operationally, in order to consolidate the development of the agro-food sector of the country and therefore enhance local agricultural production. In a more comprehensive perspective, the beneficiaries of the activity carried out by ISA are corporations and cooperative societies that receive allocations of funds, the eco-environment, thanks to the 
feasibility of power generation plants that use renewable sources, the entire agro-food sector in all parts of the chain (from production to logistics to final consumers), and others. Concerning shared value, the very meaning of the word leads to ask what is the return in terms of value creation by ISA for all activities under his care since years. Well, first of all, the ISA has, thanks to various initiatives, a broad media exposure, appearing in newspapers as "Italy Oggi", "Il Mattino", and "Il Sole 24 ore" which recognize it as a public financing entity that invests to foster the agricultural sector. The ISA can claim such an image return, as the institution provides low-interest loans and is responsible for investment operations for the food industry. Secondly, as reported on the same ISA brochures, by virtue of the partnership in a number of important initiatives in the country or not, the company has an investment portfolio concentrated in a single sector, such strong synergies with the actors of various kinds, institutional, public and not operating in the agro-industrial sector (from those in the chain to local institutions). That is not all. Given the high level of specialization required by the operations of corporate finance applied to the agricultural sector, ISA owns strongly skilled resources, which continue to increase their know-how with the consolidation and development of the ISA in time. The finance company, in support to the various agro-food businesses, adopts an ethic code by which it acquires legitimacy and social prestige in the eyes of the various stakeholders (shareholders, employees, contractors, consultants, public administrations, and etc.). The ISA, in fact, proposes to carry out its activities in compliance with fundamental human rights and principles of fairness, honesty, using clear and transparent rules which are in line with the objectives of the external environment and the community, by adopting a high standard of professionalism and excluding behaviors contrasting the law and the principles of the ISA. In conclusions, stated as its primary objective to promote aggregation processes among companies, ISA enters itself in a logic unitary system, where there is interaction and mutual exchange of resources, experience, and capacity among the various actors, in order to achieve a satisfactory result for all. In such a perspective, it could be defined as a network, used by ISA to spread value, expanding its own social skills (Richardson, 1972; Hakansson \& Snehota, 1995) and competitiveness.

\section{Findings and Discussion}

From the analysis of data collected from financial reports published by ISA (see Table 1), it is clear that his portfolio includes only investments concerning food industry. Since its constitution to $31 / 12 / 2013$, it has approved investment projects for a total of 260 million euro, of which only $0.76 \%$ currently in default, aimed at increasing the productivity of companies and/or to improve the logistics and/or structures. Of that amount, 82 million euro relate to interventions of merchant banks, while 178 million euros relate to the financing facility. Companies that benefit from these resources, contribute to gross marketable output (PLV) for agricultural commodities for 1.1 billion euro, representing total sales of around 4.4 billion euro. The observation of the data on the ISA portfolio from 2011 to 2013 shows that the number of approved projects with respect to the 82 presented is small, because of non-compliance with the provisions of the operating rules and/or the mission of the finance company. The latter, in order to limit its credit risk for each loan, evaluates, in fact, with particular attention to the adequacy and solidity of the company economic structure and financial position; the competitive position of the company/applicant and consistency between the requirements and the investment plan that the applicant proposes; the financial viability of the project in the medium-long term; the adequacy of the guarantees which must not be less than $150 \%$ in relation to the type and amount of financing; and the trend of the market. The 14 approved projects have generated a total investment of about 78 million euro, of which 38.4 million is in the form of grant awards. 
Table 1

2011-2013 ISA Portfolios-source: Elaboration on ISA Data

\begin{tabular}{llllll}
\hline Year & $\begin{array}{l}\text { No. of projects } \\
\text { submitted }\end{array}$ & $\begin{array}{l}\text { No. of project } \\
\text { approved }\end{array}$ & $\begin{array}{l}\text { Total value of project } \\
\text { approved }\end{array}$ & Grant awards & Merchant banking \\
\hline 2011 & 28 & 4 GA & $10.9 \mathrm{mln}$ & $10.9 \mathrm{mln}$ & 0 \\
\hline 2012 & 34 & $\begin{array}{l}5 \text { of which } \\
3 \text { GA and 2 MB }\end{array}$ & $36.8 \mathrm{mln}$ & $12.3 \mathrm{mln}$ & $24.5 \mathrm{mln}$ \\
\hline 2013 & 20 & $\begin{array}{l}5 \text { of which } \\
\text { 4 GA and 1 MB }\end{array}$ & $30.2 \mathrm{mln}$ & $15.2 \mathrm{mln}$ & $15 \mathrm{mln}$ \\
\hline
\end{tabular}

Looking at Table 2, as regards disbursements, in the three years considered, they totaled 86.3 million euro (also including those relating to projects approved in previous years). They mainly concerned the subsidized loans (46.3 million euro), followed by merchant banking ( 8.6 million euro), and the "chain of contracts" (31.2 million euro).

Table 2

2011-2013 ISA Disbursement-source: Elaboration on ISA Data

\begin{tabular}{|c|c|c|c|}
\hline Year & $\begin{array}{l}\text { Total value of } \\
\text { disbursements }\end{array}$ & $\begin{array}{l}\text { Type of intervention } \\
(\mathrm{GA}=\text { Grants Award }) \\
(\mathrm{CG}=\text { Capital Grants })\end{array}$ & Modality \\
\hline \multirow{3}{*}{2013} & \multirow{3}{*}{$23.2 \mathrm{mln}$} & \multirow{3}{*}{$\begin{array}{l}12.8 \mathrm{mln} \\
6 \mathrm{mln} \\
4.2 \mathrm{mln} \text { of which: } \\
2.7 \mathrm{mln} \mathrm{GA} \text { and } 1.5 \mathrm{mln} \mathrm{CG}\end{array}$} & Grants Award \\
\hline & & & Merchant banking \\
\hline & & & Program "Contratti di filiera" \\
\hline \multirow{3}{*}{2012} & \multirow{3}{*}{$29.1 \mathrm{mln}$} & \multirow{3}{*}{$\begin{array}{l}19.2 \mathrm{mln} \\
2.5 \mathrm{mln} \\
7.4 \mathrm{mln} \text { of which: } \\
3.8 \mathrm{mln} \mathrm{GA} \text { and } 3.6 \mathrm{mln} \mathrm{CG}\end{array}$} & Grants Award \\
\hline & & & Merchant banking \\
\hline & & & Program "Contratti di filiera" \\
\hline \multirow{3}{*}{2011} & \multirow{3}{*}{$34 \mathrm{mln}$} & \multirow{3}{*}{$\begin{array}{l}14.3 \mathrm{mln} \\
0.1 \mathrm{mln} \\
19.6 \mathrm{mln} \text { of which: } \\
10.6 \mathrm{mln} \text { GA and } 9 \mathrm{mln} \mathrm{CG}\end{array}$} & Grants Award \\
\hline & & & Merchant banking \\
\hline & & & Program "Contratti di filiera" \\
\hline
\end{tabular}

From 2012 to 2013, the largest number of approved projects involved private enterprises belonging to the fruit and vegetable sectors, livestock, oil, wine, and salami. They follow cooperatives belonging to the sector of canning, wine, and seeds. The methods of intervention have been mainly in the form of grant awards.

With regard to the aims of the interventions that ISA approved in 2013, they are addressed, in the case of the company "Terre d'Oltrepò", to facilitate the technological innovation of some departments of production resulting in increased production capacity, aimed at the realization of the business plan and higher salaries and the number of contributing shareholders. Investments made, once fully operational, should allow an increase of the PLV of 10 million euro, rising from 25 million to $35(+40 \%)$, and employment will be increased by $6 \%$.

The loan of over two million euro that ISA has agreed to Fazi SPA will allow the acquisition of production assets for the processing of pork meat and the development of intangible actions included in business and marketing plans.

The facilitated loans of over seven million euro will be used by Jeio Belstar Bisol Group for the acquisition of a new plant for the production of "Prosecco" and the optimization of internal logistics, through an innovative automated warehouse. This evolutionary dynamics will allow the company to increase the level of employment $(+50 \%)$ and a significant agricultural benefit arising from the purchase of domestic grapes produced in the territories included in the specification of DOC and DOCG wines resulting in higher PLV by 
over 50\% (from about 5.5 million euros to over eight million).

The capitalization of 15 million euro of the new company "OLIO DANTE" by ISA will allow, along with the same amount given by other private parties, both the completion of industrial investment and a business plan addressed primarily at international markets. They will benefit from this intervention, the company employment (89 employees annual average), and the volume of purchases of raw materials of domestic origins (over $+60 \%$ in volume with respect to what purchased by the group in 2013).

The funding of approximately four million euro granted to Granfrutta Zani involves the realization of a material investment for more efficient storage of fruit and vegetables, especially for products with higher added value. In addition to a clear improvement of the remuneration of the producers, the investment implies a significant increase of PLV (+26\%), thus exceeding 58 million euro compared to the current 46 million euro, with consequent benefit for the national fruit and vegetable producers.

Currently, ISA is evaluating the characteristics of 18 projects that, from 2014 to 2015, it may require, in the event of a positive outcome, a maximum investment of about 70 million euro.

The core business of ISA, with the currently available tools, has generated economic benefits for the public accounts of the Italian State to those who have been transferred over the years a total of 90.7 million euro, of which 18.1 is million in January 2014. This allowed to meet the expectations of the owner supra-system, which will find complete fulfillment in January 2015 with the payment of the last tranche foreseen by the rules governing the inter-systemic relationship. To this, 100.5 million euro must be added to MIPAAF distributed as dividends. Further 11.4 million euro will be paid at the beginning of December 2014 and 7.8 million euro are planned to be paid in January 2015 .

This study clearly shows that the hypothesis can be validated, as even public financing companies contribute, in some cases, to actively supporting the relevant economic sectors, although pursuing their goals of wealth creation for various categories of stakeholders.

\section{Conclusions}

The case analyzed shows how it is possible for the small agro-food businesses to face innovation and/or internationalization processes through support of a public financing company. In such a context, the fundamental role of ISA in financing projects emerges, whose risk-return profiles would, probably, be unattractive for private investors. As already underlined, the use of public financial resources generated value under several aspects. In particular, the low percentage of companies in default (only $0.76 \%$ ) has enabled the ISA to remunerate MIPAAF and participate in the consolidation of public finances. It also created value for financed companies that, through a process of growth and innovation, they have strengthened their competitive capacity ensuring and even increasing employment levels. Thus, from a theoretical point of view, the case could fall within the field of studies of the creation of shared value. This vision assigns the company a social and economic implications key role. Actions carried out by ISA, indeed, allow companies of the food sector to face with greater confidence in the critical characteristic of the context in which they operate, by implementing a dynamic evolution designed to overcome the current economic situation. Study limitations consist in the fact that the analyzed case is a virtuous one. The model of public support to private companies has not always been positive, indeed, the Italian experience is unfortunately plenty of cases of failure. For the purpose of future research, it is suggested to examine the level of profitability generated by the individual interventions by risk capital for the benefit of ISA, in order to measure the level of value created. 


\section{References}

Barile, S. (2006). Introduction to the dynamics of variety of a viable system. In S. Barile (Ed.), Firm as a system. Contributions on the viable system approach (VSA). Torino: Giappichelli.

Benn, S., Dunphy, D., \& Griffiths, A. (2014). Organizational change for corporate sustainability. New York: Routledge.

Blackburn, W. R. (2012). The sustainability handbook: The complete management guide to achieving social, economic and environmental responsibility. London: Earthscan.

Brown, L. (1981). Building a sustainable society. New York: Norton.

Buttignon, F. (1990). Business strategy and the economic value of capital. Padova: Cedam.

Calabrese, M., Bologna, L., Iandolo, F., \& Bilotta, A. (2012). Sustainability and value in enterprise-territory relationships. Proceedings from Sinergie-The territory as a field of vitality for the enterprise. Lecce, University of Salento.

Caroli, M. G. (2006). The local marketing. Strategies for the sustainable competitiveness of the territory. Torino: Franco Angeli.

Carroll, A. B. (1993). Business and society: Ethics and stakeholder management (2nd ed.). Cin-cinnati: South-Western.

Carroll, A. B., \& Buchholtz, A. (2014). Business and society: Ethics, sustainability, and stakeholder management. Stamford: South-Western College Publishing.

Castelli, P., \& Modina, M. (2010). The effects of the financial crisis on bank-enterprise. Enterprises, banking and finance. Milano: Franco Angeli.

Collis, D. J., \& Montgomery, C. A. (1999). Corporate strategy. Milano: McGraw-Hill.

Crane, A., \& Matten, D. (2007). Business ethics: Managing corporate citizenship and sustainability in the age of globalization. Oxford: Oxford University Press.

Donaldson, T., \& Preston, L. E. (1995). The stakeholder theory of the modern corporation: Concepts, evidence and implications. Academy of Management Review, 20(1), 65-91.

Edwards, A. R. (2005). The sustainability revolution, portrait of a paradigm shift. Gabriola Island: New Society Publishers.

Elkington, J. (1994). Towards the sustainable corporation: Win-win-win business strategies for sustainable development. California Management Review, 36(2), 90-100.

Evan, W. M., \& Freeman, R. E. (1988). A stakeholder theory of the modern corporation: Kantian capitalism. In T. Beauchamp, \& N. Bowie (Eds.), Ethical theory and business (pp. 75-93). Englewood Cliffs: Prentice Hall.

Faccipieri, S. (1989). Strategic analysis. In M. Rispoli (Ed.), The industrial enterprises (2nd ed.). Bologna: Il Mulino.

Freeman, R. E. (1984). Strategic management: A stakeholder approach. Boston: Pitman.

Freeman, R. E. (1994). The politics of stakeholder theory: Some future directions. Business Ethics Quarterly, 4(4), 409-421.

Freeman, R. E. (2002). A stakeholder approach to strategic management. Boston: Pitman.

Freeman, R. E., \& Mcvea, J. (2002). A stakeholder approach to strategic management. In M. Hitt, R. E. Freeman, \& J. Harrison (Eds.), Handbook of strategic management. Oxford: Blackwell.

Friedman, T. L. (2006). The world is flat (updated and expanded): A brief history of the twenty-first century. New York:Macmillan.

Gatti, M., Biferali, D., \& Volpe, L. (2009). The governance between profit and value creation. Sinergie, 79, 145-171.

Gennaro, A. (2008). Finance conditioning and theory of value: Governance and value. Roma: Aracne.

Giuliani, S. (2005). Allocated capital: Finance conditioning and theory of value. Roma: Aracne.

Golinelli, G. M. (2005). The viable system to the firm governance. Firm as a viable system. Padova: Cedam.

Golinelli, G. M., \& Gatti, M. (2007). The thought of Roberto Fazzi and the systemic approach to governance: Exploring cultural debt, advancement and doctrinal spirit of the times. Sinergie, 72, 207-255.

Golinelli, G. M., \& Volpe, L. (2012). Consonance, value, sustainability. Toward sustainable enterprise. Padova: Cedam.

Grant, R. M. (2011). Strategic analysis for business decisions. Bologna: Il Mulino.

Hakansson, H., \& Snehota, I. (1995). Developing relationships in business networks. New York: Routledge.

Hall, J., \& Vredenburg, H. (2003). The challenges of innovating for sustainable development. MIT Sloan Management Review, 45(1), 61-68.

Jensen, M. C. (2002). Value maximization, stakeholder theory and the corporate objective function. Business Ethics Quarterly, $12(2), 235-256$.

Kickul, J., \& Gundry, L. (2002). Prospecting for strategic advantage: The proactive entrepreneurial personality and small firm innovation. Journal of Small Business Management, 40(2), 85-97.

La Rocca, M. (2001). The financial structure of Italian firms: the role of the determinants tax. Finanza, Marketing e Produzione, 3, 117-141. 
Lindgreen, A., \& Swaen, V. (2010). Corporate social responsibility. International Journal of Management Reviews, 12(1), 1-1.

Marris, R. (1972). The economic theory of managerial capitalism. Torino: Einaudi.

Mcmahon, R. G. P. (2001). Growth and performance of manufacturing SMEs: The influence of financial management characteristics. International Small Business Journal, 19(3), 10-28.

McWilliams, A., \& Siegel, D. S. (2006). Corporate social responsibility: Strategic implications. Journal of management Studies, 43(1), 1-18.

Modina, M. (2012). Rating and financial structure of the firm. In M. Modina, \& V. Formisano (Eds.), Il rating tra impresa, banca e territorio. Rapporti di Ricerca Sinergie, 36, 255-258.

Ng, I. C. L., Parry, G., Smith, L. A., \& Maull, R. S. (2010). Value co-creation in complex systems: Conceptual foundations. Proceedings from Forum Markets and Marketing: Extending the Service Dominant Logic.

Payne, A., Storbacka, K., \& Frow, P. (2008). Managing the co-creation of value. Journal of the Academy of Marketing Science, 36(1), 83-96.

Porter, M., \& Kramer, M. R. (2011). The big idea: Creating shared value. Harvard Business Review, 89(1-2), 1-17.

Post, J. E., Preston, L. E., \& Sachs, S. (2002). Redefining the corporation. Stakeholder management and organizational wealth. Stanford: Stanford University Press.

Quaddus, M., \& Siddique, M. A. (2011). Sustainable development and corporate sustainability basic issues. London: Edward Elgar Publishing.

Rappaport, A. (2012). Save capitalism. How to regain control of the finance and to create long-term value. Milano: Franco Angeli.

Richardson, G. B. (1972). The organization of industry. The Economic Journal, 82, 883-897.

Rossi, D. (2014). Food for life and cluster agri-food. Retrieved from http://www.federalimentare.it/documenti/Cibus2014/OpportunitaPerInnovazione/Rossi_FederalimentareServizi.pdf

Rullani, E. (2011). Enterprise and production value in the age of complexity. Sinergie, 81, 225-242.

Savitz, A., \& Weber, K. (2006). The triple bottom line, how today's best-run companies are achieving economic, social and environmental success, and how you can too. San Francisco: Jossey Bass.

Sciarelli, S. (2002). The production of the expanded value as an objective ethics in the enterprise. Retrieved from $\mathrm{http}$ //contentegea.egeaonline.it/Articoli/produzione-del-valore-allargato-quale-obiettivo-dell-etica-nell-impresa-la.aspx

Siano, A. (2012). Communication for sustainability in the management of enterprises. Sinergie, 89, 3-23.

Valdani, E. (1992). The proactive company. A new business model to create value. Economia \& Management, 4, 55-67.

Vicari, S. (1995). Notes on value concept. Finance, Marketing and Production, 3, 45-52.

Wilson, M. (2003). Corporate sustainability: What is it and where does it come from? Ivey Business Journal, 67(6), 1-5. 